Repository June 2017rv

*Debunking the Myth of Shareholder Ownership of Companies: Some Implications for Corporate Governance and Financial Reporting

by

\author{
Prem Sikka \\ Association for Accountancy and Business Affairs, UK \\ John Stittle \\ University of Essex, UK
}

*We are grateful to Jim Haslam, Sue Ravenscroft, Paul Williams, anonymous reviewers, journal editors and participants at the 2016 Conference of the American Accounting Association's Public Interest Section for their insightful comments and suggestions.

Address for correspondence:

John Stittle

Essex Business School

University of Essex

Colchester

Essex CO4 3SQ, UK

Email: jstittle@essex.ac.uk 


\title{
Debunking the Myth of Shareholder Ownership of Companies: Some Implications for Corporate Governance and Financial Reporting
}

\begin{abstract}
The shareholder primacy model is dominant in Anglo-Saxon corporate governance and financial reporting even though it is considered to be dysfunctional and a source of crisis. The possibilities of reforms are routinely stymied with the claims that shareholders are the owners of large corporations and management should promote their interests. This paper seeks to debunk such claims. It shows that a corporation is a distinct legal person and cannot be owned by its shareholders. It argues that shareholders in contemporary corporations are owners of 'fictitious' capital which is very distinct from 'real' capital. The systemic pressures require the holders of fictitious capital to constantly buy/sell shares in pursuit of short-term gains. The paper further shows that in a globalised economy, the shareholding duration in major UK companies has shrunk and shareholders are more dispersed than ever before. They are not in any position to control or direct corporations for the benefit of other stakeholders and society generally. The paper calls for abandonment of the shareholder model of governance and calls for empowerment of stakeholders with a long-term interest in the wellbeing of corporations.
\end{abstract}

Keywords: corporate governance, share ownership, fictitious capital, stakeholders, financial reporting. 


\subsection{Introduction}

People's life chances are shaped by corporate control of food, water, medicines, air, energy, savings, jobs, news, investment, pensions and much more. Corporations run prisons, schools, roads, trains, universities, nuclear sites, defence establishments and services, which were once considered to be the domain of the state, parliamentary debates and public choices. Corporations also profit from their involvement in tax avoidance, bribery, corruption, money laundering and exploitation of employees, consumers and the environment, (Bakan, 2004; Mitchell and Sikka, 2005, 2011; Hadden et al, 2014, Sikka, 2014). The profits may not only appease markets and enrich shareholders, but also raise anxieties about control and accountability of corporations (Elliott and Atkinson, 2009; Davies, 2010; Friedman, 2010; Soederburg, 2010; Stiglitz, 2010; Meyer, 2013). In view of their public nature and government-like power, democratisation of corporations has long been on the political agenda (for example, see Bullock, 1977). However, resistance has been built around the neoliberal assertion that shareholders are "the owners of the business" and that the responsibility of corporate executives is to "conduct the business in accordance with their desires, which generally will be to make as much money as possible while conforming to the basic rules of the society" (Friedman, 1970: 32). Shareholder primacy has long been promoted as a disciplining device for efficient allocation of resources (Berle and Means, 1991; Manne, 1965) and such worldviews are amplified by neoliberal think-tanks, global organisations and policymakers to create regimes of truth (Sternberg, 2004; Organisation for Economic Cooperation and Development, 2004; European Commission, 2011). Unsurprisingly, some are convinced that the "triumph of the shareholder-oriented model of the corporation over its principal competitors is now assured" (Hansmann and Kraakman, 2001: 468).

Far from being assured, the shareholder primacy model continues to be dysfunctional. For example, in agency theory traditions the interests of managers and shareholders are supposedly aligned through performance related remuneration of executives (Jensen and Meckling, 1976), but performance related pay has "contributed to excessive risk-taking by rewarding short-term expansion" (De Larosière, 2009: 10; Bratton, 2002). In its assessment of the 2007-08 banking crash, 
the UK's Banking Standards Commission concluded that "shareholders failed to control risk-taking in banks, and indeed were criticising some for excessive conservatism" (UK Parliamentary Commission on Banking Standards, 2013: 42; UK Financial Services Authority, 2009). A "tendency to make decisions in search of immediate gratification at the expense of future returns" (Kay, 2012: 14) is a recurring feature of share ownership and shareholders rarely take interest in the long-term wellbeing of corporations. The European Commission lamented that "the majority of shareholders are passive and are often only focused on short-term profits" (European Commission, 2011: 3).

The neoliberal model of corporate governance also informs accounting calculations which arguably provide shareholders with measurements of risks, performance and rewards. George Staubus, often credited with advancing the concept of decision usefulness in financial reporting (Staubus, 2000), claimed that "Managers work ${ }^{1}$ for the shareholders in a business corporation. Shareholders seek enhancement of their wealth, so their fiduciaries, their faithful stewards must likewise seek enhancement of shareholder wealth. If maximizing cash flow potentials is shareholders' focus, it must be the focus of their stewards as well" (Staubus, 2006, para 3). Accounting textbooks legitimise the shareholder ownership model with the claim that "the prime objective of the preparation and publication of regular financial reporting is - as far as public limited companies are concerned - to provide a vehicle whereby directors can account to the owners of the company ... This involves providing shareholders with information about the progress of the company ..." (Lewis and Pendrill, 2000: 57). Such assertions persist even though financial accounting reports are of limited value to investors (Plantin, Sapra and Shin, 2008), and "do not tell the reader much of a story" (UK House of Commons Treasury Committee, 2009: 87). The European Commission (2010a) added that "The fact that numerous banks revealed huge losses from 2007 to 2009 on the positions they had held both on and off balance sheet raises not only the question of how auditors could give clean audit reports to

\footnotetext{
${ }^{1}$ It is hard to find even one example where managers of a large corporation have an employment contract with shareholders. Rather they have a contract with a corporation, which is a legal person in its own right. They have recourse against the corporation for unfair employment practices rather than against any individual shareholder.
} 
their clients for those periods but also about the suitability and adequacy of the current legislative framework" (p. 3).

The truth claims of the shareholder ownership of companies are disrupted by others. For example, Handy (1995) argues that shareholders are "more akin to punters at the races ... placing their money on their financial horses. To expect the punters who had backed the bay gelding to stay with that horse throughout its career, or to give their advice to its trainer, would not be reasonable. If they don't like its form, they transfer their money to another. Punters or speculators they may be, owners in any real sense they cannot be" (p. 63). The shareholder ownership of large companies has been described as a "myth", but despite recurring crisis it has remained dominant (Galbraith, 1961; Sikka and Willmott, 1995; Ireland, 1999; Arnold and Sikka, 2001; Walker, 2009; Stout, 2012; Collison et. al, 2014; Financial Reporting Council, 2010, 2012, 2013). In its assessment of the 2007-08 banking crash, the European Union concluded that the "financial crisis has shown that confidence in the model of the shareholder-owner who contributes to the company's long-term viability has been severely shaken, to say the least" (European Union, 2010b: 8), but the UK government asserted that "The role of shareholders as owners of companies is crucial. It is they who are best placed to assess the governance of companies and engage with their boards on key governance and other issues (UK Department of Business, 2011: 3).

Seemingly, the debunking of the shareholder primacy model is a necessary precondition for the transformation of corporations into institutions which can serve the needs of stakeholders and broader society. This paper contributes to an emerging literature which argues that the possession of shares in large companies is not synonymous with ownership of companies (Ireland, 1999, 2005, 2010; Stout, 2012). It argues that the attempts to empower shareholders cannot overcome the dynamics of capitalism which encourages them to take a short-term and passive interest in the governance of corporations. It shows that shareholders often provide a small fraction of risk capital to banks, which are an example of major corporations, and are not the major risk-bearers, and cannot be considered to be the owners. 
This paper is divided into four further sections. The first section engages with the neoliberal claims that shareholders 'own' companies. It applies a number of tests to the concept of 'ownership' from legal practice and philosophy (Honoré, 1961; Munzer, 1990) and shows that the possession of shares cannot be equated with ownership of companies. The second section engages with a populist view that shareholders own major corporations because they have invested large amounts in company shares and are therefore entitled to controlling rights. It shows that there is considerable difference between investment in 'real' capital or productive capacities of an enterprise and investment in the tradable shares, often the focus on corporate governance and financial reporting, which entitles shareholders to receive a fraction of the future economic surpluses. In fact, share capital exists in both productive and speculative forms. The latter was described by (Marx, 1978, 1981) as "fictitious capital" and its value is determined by speculation on as-yet-unproduced surplus value. The pursuit of speculative future values exacerbates uncertainties and dissuades shareholders from taking a long-term interest in companies (Cooper, 2015). The second section also shows that the duration of shareholding in major UK companies has decreased and shareholders have become more dispersed. Evidence from the UK banking sector shows that shareholders provide a very small amount of the total risk capital, something which challenges the claims that shareholders are the main bearers or risks or that they own companies. The third section considers the implications of the arguments and evidence of the preceding sections for corporate governance and financial reporting. The fourth and final section concludes the paper with a summary and discussion.

\subsection{SHAREHOLDERS AS OWNERS OF COMPANIES}

In early capitalism, individuals and families mainly traded as sole traders or partnerships and were assumed to be the owners of the business because they had direct involvement with every aspect of the management of the business. They provided financial resources; appropriated economic surpluses generated by labour, and were held personally liable for business debts and the harm caused by the business to third parties. In a partnership, all partners were jointly and severally liable for the firm's debts and the incidence of unlimited liability tended to provide a moral check on overtrading and speculative schemes. However, entrepreneurs 
began to develop contracts to reduce their liability exposure and some businesses were gradually transformed into limited partnerships. In return for lower controlling rights, some partners wanted to be passive and take little or no part in the day-to-day management of the business (Morck, 2007). There were considerable variations on the concept of limited partnerships but, in general, in return for limits on liability, the passive or sleeping partners conceded their right to manage the business (Saville, 1956, Hilt and O'Banion, 2009). Their liability was limited to the extent of capital subscribed, though they received a share of income generated by the business. The emergence of limited partnerships emphasised separation of control and ownership of businesses. Such logics informed the emergence of limited liability corporations, which unlike sole traders and partnerships functioned as separate legal persons and whose shareholders enjoyed the benefit of limited liability. Nevertheless, Talbot (2013) notes that the "Limited Liability Acts had been passed but partnership principles were still used as the yardsticks" (p.26).

In the context of large corporations with limited liability, ownership is more than a question of the possession of an asset or derivation of income from it. Any discussion of the shareholder ownership of companies has to consider the impact of legal personality accorded to corporations. The idea of ownership is always related to particular historical, cultural, and political formations (e.g. socialism, communism, state capitalism etc.). In a neoliberal context, ownership encompasses a bundle of rights, relationships with others, as well as a relationship with 'the thing' or item in question and the right to posses, occupy, use/abuse, lend out, gift, exchange, bequeath, transfer, destroy and much more.

\section{$2.1 \quad$ Incidents of Ownership}

In the Honoré (1961) and Munzer (1990) schema, ownership is characterised by incidents of rights, powers, liberties and immunities; and duty and liability. These incidents overlap to some degree and ownership is only conferred when they are present in sufficiency. The rights include (1) the right to possess: to have exclusive physical control of an asset, or to have such control as the nature of the asset admits; (2) the right to use: on a very narrow interpretation "use" relates to the owner's personal use and enjoyment of the asset owned; (3) the right to manage: the 
right to decide how and by whom the asset owned shall be used; (4) the right to the income of the asset: income in the ordinary sense (fruits, rents, profits) may be thought of as a surrogate of use, a benefit derived from forgoing personal use and allowing others to use it for reward; (5) the incident of residuarity: it is a characteristic of ownership that an owner has a residuary right in the asset owned. Whenever a lesser ownership interest terminates, the corresponding rights vest with the owners.

The idea of ownership confers powers, liberties and immunities. These include, (1) the right to the capital: the right to capital consists of the power to alienate the asset by transferring ownership to others through exchange, sale, gift and mortgage, etc. This is closely related to, (2) the power to transfer ownership to successors. (3) The liberty to consume, waste or destroy the whole of part of the asset. (4) The right to security. The owner should be able to look forward to retaining ownership indefinitely, if s/he so chooses and remains solvent. This is, in effect, immunity from expropriation, based on rules that apart from bankruptcy and execution for debt, the transmission of ownership is consensual.

Ownership confers duty and liability towards others and includes: (1) the prohibition of harmful use. An owner's liberty to use and manage the item owned as $s /$ he chooses is subject to the condition that uses harmful to other members of society are forbidden. (2) Liability to execution: the liability of the owner's interest to be taken away from him/her for debt, either by execution of a judgment debt or on insolvency.

\subsection{Ownership of Corporations}

Ever since the expansion of limited liability corporations, courts have been called upon to adjudicate disputes about the significance of share ownership and corporate control (Hunt, 1936; Kempin Jr., 1960). Legal scholars state that the UK "judicial decisions since the second half of the 19th century have made it clear beyond question that shareholders or members of a company registered under the Companies Acts have no legal or equitable interest in any part of the company's property or assets, and the company is the sole and beneficial owner of all the property vested in it. Companies can hold their assets in trust for other persons if the trust is expressly created or arises by implication or constructively under a rule of 
equity, but there is no such trust implied or imposed constructively by a rule of law or equity in favour of shareholders or members of the company as such" (Hicks and Goo, 2008: 270). Court cases have emphasised the legal separation of corporations from their shareholders. In the UK case of Short v. Treasury Commissioners [1948] 1 KB 116 122, the judges said that "shareholders are not, in the eyes of the law, part owners of the undertaking. The undertaking is something different from the totality of the shareholding".

The relationship between directors and shareholders is clarified by the UK case of Shaw \& Sons (Salford) Ltd v Shaw (1935) 2KB113. The judges said that "A company is an entity distinct alike from its shareholders and its directors. Some of its powers may, according to its Articles be exercised by directors; certain other powers may be reserved for the shareholders in General Meeting. If powers of management are vested in the directors, they and they alone can exercise those powers. The only way in which the general body of the shareholders can control the exercise of the powers vested by the Articles in the directors is by altering the Articles or, if opportunity arises under the Articles, by refusing to re-elect the directors of whose actions they disapprove. They cannot themselves usurp the powers which by the Articles are vested in the directors any more than the directors can usurp the powers vested by the Articles in the general body of shareholders".

Unlike the agency theory (Jensen and Meckling, 1976), corporate law does not grant shareholders the right to necessarily impose their will on the company. For example, court judgment in the case of Gramophone \& Typewriter Ltd v Stanley [1908] 2 KB 89 stated that "even a resolution of a numerical majority at a general meeting of the company cannot impose its will upon the directors when the articles have confided to them the control of the company affairs. The directors are not servants to obey directions given by the shareholders as individual; they are not agents appointed by and bound to serve the shareholders as their principals. They are persons who may by the regulations be entrusted with the control of the business, and if so entrusted they can be dispossessed from that control only by the statutory majority which can alter the articles". The court cases indicate that the assets of a company are owned by the company and a shareholder has no direct property interest in them (Hicks and Goo, 2008). The Companies Acts confer upon the owner of shares a complex bundle 
of rights and benefits in accordance with the specific terms of the type of share (e.g. ordinary, preference) held. These aspects are developed below.

Shareholders may possess a piece of paper entitling them to receive future income, but do not have the right to use any of the assets held by the corporation for their personal use. Under corporate law, companies are legal persons and in that capacity, they can own assets and use them in accordance with the directions given by directors. If any shareholder were to attempt to possess the asset and use it for personal enjoyment, s/he will probably be accused of theft and fraud. As the assets are legally owned and managed by the company, it can grant charges on property and also license it to third parties to generate income even without the permission of shareholders. Shareholders cannot use the assets of a company to satisfy their own debts. In common with other consumers, shareholders can use a company's assets and services by paying a price, but they generally do not have any special privileges arising from their investment in shares of the company.

Shareholders do not have a right to manage the company or the assets vested in the company in which they own shares, though they can elect directors to do so. Shareholders can vote on resolutions to constrain management, but that does not result in the right to manage assets. Most votes at annual general meetings of UK corporations are advisory rather than binding on directors.

Shareholders invest in the hope of getting a return on their investment in the future, but do not have the right to demand income from the assets owned and used by the company. Shareholders can receive dividends, but only after directors agree to declare them. In general, UK companies can only pay dividends out of accumulated realised profits (see Part 23, UK Companies Act 2006). Shareholders can vote to accept or reduce the payment of dividend, but they cannot demand a higher amount.

In principle, shareholders can hold their share certificates for an indefinite period, and can continue to enjoy the benefits derived from it as long as the company remains in existence. However, the state can nationalise industries and restrict the ability of individuals to hold shares. Shareholders cannot recover the capital represented by share certificates from the company. Of course, they can sell their 
shares to another party, but under antitrust or competition laws the state may disapprove mergers and takeovers and veto the ability of shareholder desire to buy or sell shares. Subject to the statutory controls (for example see UK Companies Act 2006, sections 641 - 653 and 658 - 737) and directors' decisions, shareholders may sell shares to the company as part of a buyback of shares. Shareholders can transfer or bequeath shares to successors, subject to the taxation laws of the country. The same also applies to using shares for gifts or mortgages. The share certificates may have some value as long as the company is solvent.

In the course of their business, companies may sell their assets, but shareholders do not have right to receive the proceeds unless directors so elect, subject to statutory rules about solvency and capital maintenance. Shareholders do have a residual interest in the event of bankruptcy, assuming that the assets have been disposed to satisfy the prior claims of secured and unsecured creditors. In practice, shareholders may receive little or nothing. According to legal arrangements shareholders bear the residuary risks, but unlike employees they can manage some of their risks by holding diversified portfolios. In economic theory there are considerable similarities between the position of a shareholder and a debt holder. Both are outside the corporation and both have provided money to a company in expectation of a return. The return due to debt holders may be written into a contract and needs to be paid before payment of any dividends, but neither is guaranteed income or the return of the original loan or investment. However, company directors can arbitrage on tax rates and leverage corporations in the hope of reducing the cost of capital and enhancing shareholder returns (Modigliani and Miller, 1958, 1963). In a leveraged firm, the value of the firm will be the sum total of debt and equity, but leveraging also has other consequences. The option pricing theory (Black and Scholes, 1973) argues that in a leveraged firm shareholders have effectively acquired a call option (this is a right, but not an obligation, to buy) on the firm's value, at least until debt matures. If on that date the value of the firm is greater than the value of debt, then the debt is worth redeeming. If the value of the firm is less than the value of the debt, shareholders are protected by limited liability and can dump the firm on to debt holders and walk away and limit their residual risk. As most major companies have some leverage, they cannot be considered to belong exclusively to shareholders, even if arguments about shareholder ownership are accepted. 
There is considerable evidence to suggest that in pursuit of higher profits and shareholder returns, companies have engaged in harmful actions, including genocide, cartels, tax avoidance, bribery and corruption (Black, 2001; Bratton, 2002; Bakan 2004; Connor, 2007, Hawley, 2000). The pursuit of shareholder wealth maximisation necessarily brings companies in conflict with others. Harmful actions may increase returns to shareholders, but also blight the lives of many people. Shareholders may receive a higher return, but they cannot be individually held responsible for the consequences of harmful actions by their companies. Shareholders can attend annual general meetings and extraordinary meetings to vote on resolutions and ask questions about harmful practices, but they cannot bind directors to follow a particular business strategy. If a company is found guilty of harmful/illegal practices, shareholders cannot be asked to compensate the victims as their liability is limited to the extent of their share capital. The ultimate sanction is that shareholders can liquidate the company engaged in harmful practices, but that is rare. The state can liquidate a corporation engaged in harmful practices even against the express wishes of its shareholders, but shareholders are not required to make good the damage done to other stakeholders. Seemingly, the corporate veil permits shareholders to benefit from practices, which as natural persons they would not be able to.

To sum up, the claims of the shareholder supremacy rely on the assumption that shareholders own corporations, a point central to neoliberal theories of corporate governance. However, from the Honoré' (1961) and Munzer (1990) perspective, shareholders are not the owners of corporations as they fail most of the tests associated with ownership. Shareholders cannot possess or use any of the assets held by a corporation. They cannot dictate business strategy, control the sale of assets, demand dividends or be held liable for a corporation's actions. They may claim residuary interest by liquidating the corporations but there is no guarantee that they will receive anything. The property of a company is entirely separate from the ownership rights of individual shareholders. Shareholders have entitlement to receive income and this is accompanied by limited liability and social irresponsibility.

\subsection{SHAREHOLDERS AS SHORT-TERM TRADERS AND SPECULATORS}


The preceding section argued that, at best, shareholders have a claim to a future surplus generated by corporate operations, which does not make them owners of corporations. This weakens the legitimacy of their controlling property rights though some may defend the status-quo by arguing that shareholders invest substantial amounts of money in companies and should therefore have the rights. Such a claim is highly contestable. The data from the London Stock Exchange, one of the world's largest stock markets, shows that around $£ 5.3$ billion is spent every day on the equities trade (London Stock Exchange, 2015). However, most of the stock market transactions are between buyers and sellers for shares already in circulation and none of the monies go directly to the companies to enable them to invest in productive facilities. Historically, a very small amount of new finance for direct investment in production has actually been raised from shareholders through the stock markets (Kay, 2012; Arnold, 2013). Large corporations have predominantly funded their investment in productive assets through retained earnings and debt (O'Sullivan, 2000). Between 2001 and 2005, equity issuance across 51 major countries came to $1 \%$ of GDP and this also includes new companies being floated on the stock market ${ }^{2}$ (Somerset-Webb, 2015). Increasingly, capital markets function as machines for value extraction rather than investment in productive assets as investors exert pressures for higher returns (Myners, 2001). The Bank of England's chief economist noted that "Among UK companies, share buybacks have consistently exceeded share issuance over the past decade, albeit to a lesser degree more recently .... In other words, over the past decade the equity market no longer appears to have been a source of net new financing to the UK corporate sector" (Haldane, 2015: 12). For the period, 2003 to 2012, Standard and Poor's (S\&P) 500 companies used $54 \%$ of their earnings - a total of $\$ 2.4$ trillion - to buy back their own shares. An additional $37 \%$ of earnings were absorbed by dividend payments (Lazonick, 2014). The trend is accelerating ${ }^{3}$ and, in 2014, the same companies returned nearly $\$ 904$ billion through dividends and share buybacks, an

\footnotetext{
2 Somerset-Webb (2015) also notes that in 2013 and 2014, US companies raised about $\$ 300$ bn selling new shares into the market. But in 2014 alone they spent $\$ 553$ bn buying back their shares.

${ }^{3}$ Wall Street Journal, Record Year for S\&P 500 Dividends, Buybacks Combined, 23 March 2015

(http://blogs.wsj.com/cfo/2015/03/23/record-year-for-sp-500-dividends-buybacks-combined-sp/).
} 
increase of $15 \%$ over 2013. An analysis ${ }^{4}$ of 1,900 US companies that have repurchased their shares between 2010 and 2015 showed that share buybacks and dividends amounted to $113 \%$ of their capital spending, compared with $60 \%$ in 2000 and $38 \%$ in 1990. Empirical evidence suggests that UK and the US private companies invest a greater proportion of their profits into productive assets compared to their listed counterparts (Asker, Collard-Wexler and De Loecker, 2014; Davies et al., 2014). The biggest casualty of the shareholder pressure for short-term returns are low investment, loss in jobs, lack of real growth in wages and erosion of the purchasing power of normal people, all key elements of a recurring economic crisis. The next subsection explains the nature of capital exchanged in stock markets and why it is speculative and encourages shareholders to be less active and focus on the short-term, something which dilutes their claims of being owners of large companies.

\subsection{Share Capital as Both Productive and Speculative Investment}

The neoliberal emphasis on shareholder rights makes virtually no distinction between productive and speculative investment, and is thus unable to explain the persistence of shareholder passiveness and the tendency of pursue short-term gains. The reasons for shareholder concentration on short-term gains and low involvement in corporate governance are embedded within the dynamics of capitalism (Harvey, 2010). The starting point is the appreciation that capital is engaged in a permanent quest for its expansion and seeks to mould the institutional structures necessary to advance its interests. Its forces are unleashed in the circuit of capital (Marx, 1978, 1981). The circuit of capital refers to the system of production, circulation, and distribution. It begins with the capitalist acquiring money and selecting appropriate technology and organisational form for his/her business. Money is the most fluid and key element in the circulation and reproduction of capital. It is transformed into capital when it enters the production process and loses some of its fluidity as the capitalist uses the money to purchase commodity inputs, including labour-power and other means of production. By combining labour power

\footnotetext{
${ }^{4}$ Reuters, The Cannibalized Company: As stock buybacks reach historic levels, signs that corporate America is undermining itself, 16 November 2015 (http://www.reuters.com/investigates/specialreport/usa-buybacks-cannibalized/).
} 
with other factors of production, the capitalist produces commodities whose value is bigger than the value of the commodities entering the production process. The capitalist now returns to the market in the hope of exchanging his/her commodity for profit. Capital regains fluidity in the form of money when the commodity is sold, but the part paid to labour is consumed, whilst another part may be saved.

After making profit, the capitalist can return to the market again and use money to purchase further quantities of labour-power and other factors of production and continue with the expanded cycle. The part that is reinvested once again becomes capital and is less fluid. The money entering the production process becomes capital and can become stuck in a particular variety of plant, machinery, product/service and geographical location. Its productivity and mobility can be increased by moving the production process from one location to another or by changing the mix of the factors of production, but the possibilities of that are constrained. In a dynamic environment, there is a danger that due to the actions of competitors, oversupply, a falling rate of return, technological innovations, changes in fads/fashion, or the inability to sell the product, the capitalist will not be able to generate a surplus or even recoup his/her investment. So the capitalist is amendable to risk management strategies which can turn capital to money. One way of turning capital locked up in the production process into money is by the development of tradable securities (e.g. shares) and selling claims on future surpluses to external, often anonymous, parties. This enables the capitalist to manage and disperse his/her risks. As a result two streams of capital are discernible. The first relates to the real investment in the production process. The second is the creation of future entitlements to surplus value which do not directly lead to any investment in the production process and is described by Marx as "fictitious capital" (Marx, 1978, 1981).

Marx explained the distinction between real and fictitious capital as follows: "The shares in railways, mining, shipping companies, etc, represent real capital, i.e. capital invested and functioning in these enterprises, or the sum of money that was advanced by the share-holders to be spent in these enterprises as capital ... But the capital does not exist twice over, once as the capital value of the ownership titles, the shares, and then again as the capital actually invested or to be invested in the enterprises in question. It exists only in the latter form, and the share is nothing but 
an ownership title, pro rata, to the surplus-value which this capital is to realise. A may sell this title to $B$, and $B$ may sell it to $C$. These transactions have no essential effect on the matter. A or B has then transformed his title into capital, but $\mathrm{C}$ has transformed his capital into a mere ownership title to the surplus-value expected from this share capital" (Marx, 1978: 597-588). In this analysis, the shareholder (C) necessarily engages in speculation about future losses or gains. This shareholder does not make direct investment in production capital but hopes to receive a proportion of future economic surpluses, which are entirely dependent on the operations of real capital.

Shares in the form of fictitious capital are bought and sold in the stock market and need not necessarily have a direct link with real capital, and all kinds of speculative bubbles can be created. Fictitious capital does not produce any surplus value as that is created by the production process. Marx argued that "the rise or fall in value of these securities is independent of the movement in the value of the real capital that they represent, the wealth of the nation is just as great afterwards as before. ... As long as their depreciation was not the expression of any standstill in production and in railway and canal traffic, or an abandonment of undertakings already begun, or a squandering of capital in positively worthless enterprises, the nation was not a penny poorer by the bursting of these soap bubbles of nominal money capital ... All these securities actually represent nothing but accumulated claims, or legal titles, to future production. Their money or capital value either does not represent capital at all ... or is determined independently of the value of real capital value they represent" (Marx, 1981: 599). The important point is that once the entitlement to future economic surpluses can be traded, the capitalist is no longer directly bound to the production process and need not take as much interest in it as s/he did previously. If the fictitious capital held by an individual is a small part of his/her total wealth, then s/he may be inclined to take even less direct interest in the performance of real capital. The trade in shares does not eliminate risks as the holder of fictitious capital becomes more concerned about factors which might affect future values and surpluses and has to constantly engage in buying and selling shares.

The emergent form of passiveness and separation from ownership were not universally welcomed as they created new moral hazards. Adam Smith (1776) noted 
that "in a private copartnery, each partner is bound for the debts contracted by the company, to the whole extent of his fortune. In a joint-stock company ${ }^{5}$, on the contrary, each partner is bound only to the extent of his share" (p. 606). In Smith's thought, the incidence of personal liability dealt with the agency problem and moral hazards. In contrast, the emerging forms of managerial capitalism and limited liability encouraged passivity and neglect. Smith argued that "The trade of a joint-stock company is always managed by a court of directors. This court, indeed, is frequently subject, in many respects, to the control of a general court of proprietors. But the greater part of these proprietors seldom pretend to understand any thing of the business of the company; and when the spirit of faction happens not to prevail among them, give themselves no trouble about it, but receive contentedly such halfyearly or yearly dividend as the directors think proper to make to them. This total exemption front trouble and front risk, beyond a limited sum, encourages many people to become adventurers in joint-stock companies, who would, upon no account, hazard their fortunes in any private copartnery" (p.606). Smith then cautions against managerial capitalism by stating that the "directors of such companies, however, being the managers rather of other people's money than of their own, it cannot well be expected that they should watch over it with the same anxious vigilance with which the partners in a private copartnery frequently watch over their own. ... Negligence and profusion, therefore, must always prevail, more or less, in the management of the affairs of such a company" (pp. 606-607).

In early forms of capitalist enterprises, such as sole traders and partnerships, capitalist was closely bound to the production process. The economic surpluses were generated by labour, but the prevailing social relations of power permitted the providers of finance to appropriate them. From the eighteenth century onwards, a variety of organisational forms began to develop and these greatly increased the fluidity of capital. These included companies chartered by the state (such as the East India Company) which were often formed for a specific purpose (e.g. trade, building canals, roads). They enjoyed a government of their own but did not have perpetual life and their charters required frequent renewals and could be revised or rescinded by the state (Ciepley, 2013). Thus, the purpose of early corporations was strictly

\footnotetext{
${ }^{5}$ In Smith's time, this was the nearest equivalent to the modern limited liability company. He appears to be mainly referring to the companies chartered by the state, such as the East India Company.
} 
controlled and limited liability (for example see UK's Joint-Stock Companies Act 1844 and Limited Liability Act 1855) was reserved for "special case" of companies engaged in capital-intensive sectors (Bowman et al., 2015). The objective was not necessarily to maximise shareholder wealth, but to undertake specific tasks and if they were not fulfilled then the privileges, including limited liability, could be withdrawn. The attainment of objectives was not accomplished by some invisible hand, but rather by the graft of those working for the corporation.

The above did not satisfy elites and eventually the Limited Liability Act 1855 and the Joint Stock Companies Act 1856 expanded the possibility of easily forming limited liability companies and restricting shareholder liability to the extent of paid-up share capital regardless of the indebtedness of the company and the damage that it might do to society at large (Micklethwait and Wooldridge, 2005). The concessions to financial elites could be rationalised as part of a social bargain whereby "government granted loss-limits for investors on the understanding they would put something back by helping to build the nation's infrastructure for the benefit of the social weal" (Bowman et al., 2015: chapter 5). Nevertheless, the protection of the state was a triumph for wealthy elites because "Without limited liability, the wealthy commercial capitalists and financial aristocracy, from whom the bulk of industrial capital would ultimately have to come, but who had the most to lose, would not invest. ... there was a clamour for limited liability, to convince the 'great capitalists' that abandoning their privileged access to it via statutory companies would eventually bring them even greater riches" (Bryer, 1997: 40). The resulting corporations appear to be private in that they are not directly run or funded by governments, or staffed by state employees. However, corporations also have public characteristics in that unlike local clubs and voluntary associations, they cannot be formed without public laws and rely upon the state to enforce their property rights. They are dependent upon citizens for their finance, sales, purchases and labour. Whilst tensions between the public and private have not been dissolved (Ciepley, 2013), neoliberals claim that shareholders can somehow come together and take collective action to invigilate companies. The next subsection challenges such arguments. 


\subsection{Shareholding Patterns in the UK}

The preceding subsection argued that shareholders, as holders of fictitious capital, are separated from real capital, and manage their risks by constantly buying and selling shares. Some support for such a claim is provided by shrinkage of the duration of shareholding in major UK companies. Andrew Haldane, chief economist at the Bank of England, noted that, for the UK, the "average duration of equity holdings has fallen from around 5 years in the mid-1960s to around 2 years in the 1980s. At the turn of the century, it had reached just over a year. By 2007, it had fallen to around $7 \frac{1}{2}$ months ${ }^{6 "}$ (Haldane, 2010: 16). The average duration of shareholdings in the US, UK and European banks "fell from around 3 years in 1998 to around 3 months in 2008. Banking became quite literally, quarterly capitalism" (Haldane, 2011a: 12). The shareholding period in 2015 may well be around one month ${ }^{7}$. With automated computer trading the shareholding duration is likely to shrink further as the average time for which a stock is held before being traded again has been reduced to 22 seconds $^{8}$, a time horizon which is not compatible with any of the neoliberal claims about shareholder ownership of companies. The average shareholding period has declined even though successive UK governments have sought to deepen share ownership through privatization of state owned enterprises and offering shares to ordinary people at heavily discounted prices (Roland, 2008). Governments have offered taxation inducements to encourage share ownership ${ }^{9}$. Through pension schemes and savings plans, many individuals have become indirect shareholders or conscripted capitalists though they have little say in how their savings are invested and can rarely call pension fund managers to account.

\footnotetext{
${ }^{6}$ Haldane (2010) notes that "In 1940, the mean duration of US equity holdings by investors was around 7 years. For the next 35 years up until the mid-1970s, this average holding period was little changed. But in the subsequent 35 years average holding periods have fallen spectacularly. By the time of the stock market crash in 1987, the average duration of US equity holdings had fallen to under 2 years. By the turn of the century, it had fallen below one year. By 2007, it was around 7 months" (p. 16).

7 The Daily Telegraph, Thatcher's dream for UK investors has become a nightmare, 17 May 2015 (http://www.telegraph.co.uk/finance/11610490/Thatchers-dream-for-UK-investors-has-become-anightmare.html).

${ }^{8}$ The Daily Telegraph, How long does the average share holding last? Just 22 seconds, 18 January 2012 (http://www.telegraph.co.uk/finance/personalfinance/investing/9021946/How-long-does-the-averageshare-holding-last-Just-22-seconds.html).

${ }^{9}$ Since 1999, the UK government has promoted Individual Savings Account (ISA). ISA is a successor to previous schemes known as Tax-Exempt Special Savings Account (TESSA) and Personal Equity Plan (PEP). These gave individuals tax concessions for direct investment in company shares.
} 
The incessant need to engage in speculative activity has transformed the pattern of shareholding in UK companies. At the end of 2014, shares in quoted UK domiciled companies were valued at around £1,726.8 billion (UK Office for National Statistics, 2015). The data in Table 1 may be complex and open to a variety of interpretations (Kay, 2012), but some clear patterns are evident.

\section{INSERT TABLE 1 HERE}

Table 1 shows that despite prolonged efforts, including privatisations and tax concessions, the percentage of shares held by individuals has declined from a high of $54 \%$ in 1963 to $11.9 \%$ in 2014 . One explanation is that with recurring financial scandals "People have generally become less trusting in financial markets and shares in particular ... individual risk-averse investors have become more worried about picking individual stocks ${ }^{10 "}$ and have switched to alternative forms of investment, such as unit trusts. In any case domestic investors now have access to previously inaccessible markets in China, India and other emerging markets. The institutional investors (insurance companies, pension funds, unit trusts, investment trusts, banks and other financial institutions) held about $30 \%$ of the issued share capital of companies quoted on the London Stock Exchange in 1963, and by 2014 it had declined to about $28 \%$. The institutional investors have been urged by policymakers to take a long-term interest in companies and hold regular meetings with company executives (Committee on the Financial aspects of Corporate Governance, 1992, 1998), but industry insiders claim that they are concerned about the impact of a financial crisis and have reduced their risk exposure by switching from shares to bonds ${ }^{11}$." In any case, the managers of institutional investors are subject to short-term performance evaluations and have become strident in extracting cash (Myners, 2001). Haldane (2015) notes that in 1970, UK companies paid out about $£ 10$ out of each $£ 100$ of profits in dividends, but by 2015 the amount was between $£ 60$ and $£ 70$, often accompanied by a squeeze on labour and investment. A body of research shows that under pressure from institutional shareholders, in the period leading to the 2007-08 financial crash, banks took bigger

\footnotetext{
${ }^{10}$ Financial Times, Chart that tells a story - UK share ownership, 4 September 2015 (https://www.ft.com/content/14cda94c-5163-11e5-b029-b9d50a74fd14; accessed 19 October 2016).

${ }^{11}$ Financial Times, Chart that tells a story - UK share ownership, 4 September 2015 (https://www.ft.com/content/14cda94c-5163-11e5-b029-b9d50a74fd14; accessed 19 October 2016).
} 
risks and experienced larger losses (Erkens, Hung and Matos, 2012). A parliamentary inquiry into the banking crash noted that institutional investors "were scarcely alert to the risks to their investments prior to the crash, but were mesmerised by the short-term returns ..." (UK Parliamentary Commission on Banking Standards, 2013: 22).

Neoliberalism has facilitated mobility of capital by dismantling barriers and capital is no longer constrained by any geographical boundaries (Harvey, 2010). The UK has been in the forefront of such developments and has experienced a massive shift in the pattern of shareholdings by individuals and organization from outside the UK. Their holding of shares in UK listed companies increased from $7 \%$ in 1963 to $28 \%$ in 1997 and $53.6 \%$ in 2014. An explanation offered by the UK government's statistical agency is that the changes since the 1990s reflect the growth in international mergers and acquisitions, and the ease of overseas residents to invest in shares quoted on the UK market (UK Office for National Statistics, 2015). However, others suspect that the high dividends by UK listed companies are a magnet for foreign investors, especially when they can use tax havens to conceal their identity ${ }^{12}$. Whichever way one looks at it the increase in foreign ownership means that shareholders are highly dispersed and unlikely to be in a position to act in any collective way to guide and invigilate companies. Foreign share ownership raises the spectre that, in pursuit of higher returns, investors can engage in abrupt and largescale trades and thus add volatility to credit markets, interest rates, trade deficits, cash flows and economic policies pursued by the local state (Jackson, 2008). Some may welcome foreign ownership and control of companies as a sign of health of the UK companies whilst others are concerned about 'cherry-picking' prospect of cash flowing out and that distant owners are less responsive to local needs (Sharman, 2013). Foreign shareholders do not directly experience the prices or quality of products and services provided by companies they are unlikely to show solidarity with local consumers or be in a position to take action on behalf of local communities. One commentator argued that "When our companies are controlled from abroad, we lose a sense of common interest with the people who actually live

\footnotetext{
${ }^{12}$ The Guardian, Stock market shifts mean Britain is under foreign ownership, 28 September 2013. (https://www.theguardian.com/money/blog/2013/sep/28/stock-market-britain-under-foreign-ownership; accessed 19 October 2016).
} 
here. Foreign shareholders have no interest in the schools and hospitals here that are paid for from corporation tax, and they will do their utmost to avoid tax by squirreling the money through one offshore tax haven to the next ${ }^{13}$ ".

A commonly held view is that shareholders provide the bulk of risk capital and should thus enjoy controlling rights. Table 2 looks at the balance sheets of major UK banks. The banks provide an interesting example because they have been strong advocates of the shareholder primacy model and have developed complex financial instruments to enhance shareholder returns (Davies, 2010; Stiglitz, 2010)

\section{INSERT TABLE 2 HERE}

Following a series of mergers and bailouts, the UK banking sector is dominated by just five groups ${ }^{14}$. Whilst the concept of risk capital can have numerous meanings, Table 2 shows that the funds attributed to shareholders in the balance sheets of banks range from $5.82 \%$ to $8.19 \%$ of the total assets. This means that the banks are primarily relying on the financial resources provided by debt financing and savers to generate higher returns for their shareholders. Banks have also been bailed out by taxpayers, but neither savers nor taxpayers are represented in the shareholder centric model of corporate governance.

\subsection{Implications for Corporate Governance and Financial Reporting}

The previous sections have sought to debunk the claims of shareholder ownership of companies. Shareholders do not own companies, the duration of shareholding has shrunk; shareholders contribute little of the risk capital and do not bear the residuary risks. The composition of shareholders has changed and they are more dispersed than ever before. Shareholders whether in the form of hedge funds, private equity, domestic, foreign, individual or institutional investors cannot easily transcend the imperatives of a social system which requires them to constantly buy/sell shares in order to enhance fluidity of capital and secure short-term returns. Such a pursuit

\footnotetext{
${ }^{13}$ The Guardian, Stock market shifts mean Britain is under foreign ownership, 28 September 2013 (http://www.theguardian.com/money/blog/2013/sep/28/stock-market-britain-under-foreign-ownership).

${ }^{14}$ There are also a number of other banks, but they are comparatively small and predominantly part of nonbanking organisations, such as Tesco Bank and Sainsbury's which are owned by supermarkets. Harrods Bank and Marks and Spencer Bank are owned by departmental stores.
} 
necessarily creates a distance between shareholders and companies. Institutional investors may take an episodic interest in matters such as executive remuneration, but have generally exerted pressures on management to increase shareholder value even if that entails risky strategies (Gong, 2014). The UK regulators have issued codes such as the Stewardship Code (Financial Reporting Council, 2012) which prescribes role and responsibility of institutional shareholders, but it is framed by concerns to enhance shareholder value. The proposals to displace the shareholder model of corporate governance are resisted with the claim it promotes economic efficiency (Demsetz, 1969); though the fallout from the 2007-08 banking crash resulting in huge state sponsored bailouts and austerity programmes would seriously challenge such claims (Stiglitz, 2010). One conclusion from a study of the banking crash is that the shareholder model of "Corporate governance not only failed to prevent the financial crisis, but actually encouraged and permitted corporations to create and take excessive financial and business risks for short-term profit maximization" (Sun, Stewart and Pollard, 2011: 7). The inescapable conclusion is that limited liability permits managers and shareholders to indulge in speculative and harmful practices without incurring any personal risks or liability. The shareholder centred model of governance has become so dysfunctional that the Managing Director of Waitrose, a major UK supermarket, said that "companies which prioritise shareholder value are responsible for the lack of trust in business ${ }^{15}$."

\subsection{Contours of New Corporate Governance}

No model of corporate governance can dissolve contradictions of capitalism as they are embedded within the system which is inherently crisis prone (O'Connor, 1987). It cannot eliminate social antagonisms over appropriation of economic surpluses. Major reforms to corporate governance can shape trajectories of capitalism by empowering groups with a long-term interest in a company and less power for those with short-term and speculative interests. There is increasing recognition that shareholder primacy is dysfunctional and has encouraged short-termism, tax avoidance and anti-social practices at the expense of employees, taxpayers and

\footnotetext{
15 The Daily Telegraph, Waitrose boss Mark Price says Britain should turn its back on capitalism, 10 November 2015.

(http://www.telegraph.co.uk/finance/newsbysector/retailandconsumer/11986665/READY-Waitroseboss-Mark-Price-declares-Britain-should-turn-its-back-on-capitalism.html; accessed 20 April 2016).
} 
other social constituencies. A starting point for an alternative conceptualisation is that a corporation cannot simply be understood as an asset which is under the control or ownership of a particular group such as shareholders. In the legal context, a corporation is a distinct legal person and owns itself, but its assets and wealth are the outcome of the contributions made by diverse stakeholders through a network of enduring economic and social relationships. From this perspective, corporations are social and political rather than private entities and their governance is not the sole preserve of shareholders, and neither can their managers' accountability be confined to shareholders (Willmott and Veldman, 2016).

Any emancipatory change in corporate governance would need to increase space of stakeholder rights by diluting the controlling rights enjoyed by shareholders, especially as they add to instabilities of the system and do not promote the long-term wellbeing of a company. But how is to be achieved? The power of shareholders, especially those who are primarily speculators and traders, may be diluted by requiring them to hold shares for a minimum period (say 12 months) before they can exercise any controlling rights. Some may wish to reward those who take long-term interest and those holding shares beyond a specified period may be granted additional dividends or voting rights ${ }^{16}$, but this may militate against their continuous quest for higher short-term returns. Another possibility is that the benefit of limited liability could be removed from shareholders so that they are personally liable for a corporation's debts. Faced with the prospect of personal liability, shareholders may take sustained interest in the wellbeing of a company and could exert pressures on directors to moderate corporate practices. Such a change will no doubt face considerable opposition and neoliberals will dissuade governments by raising fears about investment and jobs. The above may limit the influence of speculators and traders on corporate governance but would still require the enterprise to operate according to the logic of the shareholder primacy model, and may not empower other stakeholders who help to build value of the business.

A way forward would be to reconceptualise the corporation as a social institution whose main responsibility is to advance the interests of its stakeholders (Dodd,

\footnotetext{
${ }^{16}$ For example, the 2014 Florange Act in France awards double voting rights to shares registered for two
} years. 
1932). Such an approach to corporate governance needs to be founded on emancipatory principles (Greenfield, 2006), which require that the ultimate purpose of a corporation is to serve the interests of society as a whole; they must contribute to the societal good by creating financial prosperity; laws must be enacted and enforced to ensure that corporations do not deviate from the above two principles; the wealth generated by a corporation should be shared fairly by all those who contribute to its creation; and governance of the corporation must be democratised. The above conceptualisation recognises that a corporation is a distinct entity which is separate from its shareholders and is a stakeholder rather than a shareholderowned entity. In this context, unlike the agency theory (Jenson and Meckling, 1976) directors are positioned as trustees of stakeholders rather than agents of shareholders. Their duty would be to increase value of the business and to allocate it fairly to all stakeholders. Thus, trustees will have a duty of care to all stakeholders rather than just shareholders. In this structure, shareholders may retain the benefit of liability, but would not enjoy the exclusive controlling rights. Stakeholders with longterm interests, such as employees, local communities, customers and suppliers, would enjoy the controlling statutory rights and have powers to appoint directors, receive accounts, and call directors to account. The above suggestion is distinct from the two-tier or supervisory board structures in some European countries which facilitates employee participation in major companies whilst shareholders exercise diluted controlling rights (Du Plessis et al., 2012). The two-tier boards fuse elements of corporate and labour laws. In the UK's unitary board system, labour relations and possible struggles over share of economic surpluses are placed outside the corporation, whilst in the two-tier system they are brought within the corporation. The two-tier model may represent a pragmatic compromise between labour and capital, but does not change the antagonistic nature of capitalism. The challenge would be to align the interests of directors with the interests of stakeholders. The abandonment or dilution of the shareholder centric model of corporate governance has the potential to redirect energies so that rather than being solely the plaything of shareholders, corporations can become institutions for economic development to improve the lives of stakeholders, their families, local community and society generally.

\subsection{Stakeholder Reporting}


A shift towards a stakeholder model of corporate governance would need to be accompanied by changes to the current system of financial reporting which reinforces the shareholder primacy model of governance and has played a key role in manufacturing short-term shareholder returns and hollowing out companies (Cooper, 2015; Haslam et al., 2015). The contemporary financial reporting system remains primarily focused on the provision of financial information to "existing and potential investors, lenders and other creditors in making decisions about providing resources to the entity. ... Those decisions involve buying, selling or holding equity and debt instruments, and providing or settling loans and other forms of credit ... they are the primary users to whom general purpose financial reports are directed" (IASB, 2011). Accounting standard setters are unable to define the meaning and nature of "equity" in company balance sheets (Pope and Puxty, 1991), but in pursuit of the ideological advance of shareholder power the IASB asserts that "the external users whose needs are paramount are those who have a claim on the entity - equity investors and creditors" (IASB, 2007).

The shareholder-centric model promoted by accounting standard setters assumes that investors are rational utility maximizers, and use financial reports to make predictions about future cash flows to aid them in buying and selling securities. Thus, financial reports mimic markets and exacerbate uncertainties and instabilities inherent in the system (Haldane, 2011b). The predictive value criterion embedded in contemporary accounting standards does not seem to easily flow from UK corporate laws. For example, in the UK House of Lords judgment in Caparo Industries plc v Dickman [1990] 2 AC 605, the judge said: "I do not believe and I see no grounds for believing that, in enacting the statutory provisions, Parliament had in mind the provision of information for the assistance of purchasers of shares or debentures in the market, whether they be already the holders of shares or other securities or persons having no previous proprietary interest in the company ... one purpose of providing the statutory information might be to enable the recipient to exercise whatever rights he has in relation to his proprietary interest by virtue of which he receives it, by way, for instance, of disposing of that interest. I can, however, see no ground for supposing that the legislature was intending to foster a market for the existing holders of shares or debentures by providing information for the purpose of 
enabling them to acquire such securities from other holders who might be minded to sell" (page 39). The above suggests that accounting standard setters have taken it upon themselves to align financial reporting with the interests of shareholders making speculative investments.

A key requirement of the stakeholder reporting model would be to report whether corporations have served the interests of society as a whole. This may require a variety of qualitative and quantitative forms of financial reporting. In the recent past, there were hints that financial reporting might address the information needs of a plurality of stakeholders (American Institute of Certified Public Accountants, 1973; Accounting Standards Steering Committee, 1975), but with the rise of neoliberalism such concerns were abandoned. They may need to be revisited. A fuller stakeholder reporting system may build on some existing practices and may equally abandon its worse aspects. For example, all wealth generation requires cooperation, grudging or otherwise, amongst stakeholders, but the income statement prepared in accordance with contemporary theories neglects such matters. It regards payments to providers of labour in the forms of wages and salaries as a 'cost' or a burden. The payment to society for the provision of social infrastructure in the form of taxes is also treated as a cost. In contrast, the payment of dividends to shareholders is considered to be rewards. The ideological logic embedded in income statements is that managers must reduce wages and avoid taxes to maximise shareholder returns (Sikka, 2015). Such logics have fuelled inequalities in the distribution of income and wealth. A stakeholder model of income statement would need to move away from the celebration of the victory of capital over labour and instead emphasise the value created by corporations, possibly in the shape of a value added statement (RiahiBelkaoui, 1999). It is then a matter for the stakeholders or boards elected by them to decide how this value-added is to be apportioned. An alternative approach suggested by Sunder (2008) recognises that wealth generation is a co-operative effort and uses well-known economic methods to calculate income and value e.g. the value of the firm is the present value of future cash flows. Here the goal of the firm is to produce economic surpluses (i.e. outputs exceed inputs) and these are distributed to each factor of production on the basis of the contribution made to wealth generation. The income accruing to each stakeholder is the difference between his/her receipts and contributions to wealth generation. Its capital value can be 
calculated by using an appropriate social discount rate. Such a system has the capacity to report the total surplus generated by the firm and the share of wealth allocated to each contributor. Of course, the measurement and allocation of surpluses would still need appropriate governance structures and would be subject to political debates as each contributor may seek to maximise his/her income.

In the current system of financial reporting, stakeholder concerns are treated as externalities and largely ignored, possibly because the absence of markets makes it difficult to obtain financial estimates. Consequently, the reports say little, if anything, about the impact of corporations on people's health (for example through the sale of harmful products), inequalities, human rights violations, pollution, jobs, or local communities. However, not everything of social importance can be reduced to financial estimates nor is it desirable that anything that can't be reduced to financial numbers be ignored. Corporations can provide statistics about minority hiring, the number of employees on the minimum wage, the absence of women from the upper echelons, injuries from consumption of corporate goods/services and much more. Companies may incur fines for environmental damage, tax avoidance/evasion, bribery, corruption, discrimination and other anti-social practices, and corporate laws and financial reporting rules emphasise that directors should give a truthful account of material costs incurred in pursuit of shareholder wealth maximisation. The same should also apply in relation to matters that affect society at large. The imposition of a duty of care to all stakeholders has the capacity to encourage directors to think differently about their decision-making and its consequences. The need to report externalities means that the issues become visible and company directors would need systems to collect the information and reflect on its consequences. It is difficult to see how the contribution of a corporation to society can be gauged by governments, policymakers, communities or stakeholders without qualitative and/or quantitative attention to social costs. The consideration of social costs presents considerable challenges, but that alone does not justify neglect (Bebbington and Gray, 2001).

The disclosures, whether in financial reports or elsewhere, should be governed by the needs of society rather than the speculative impulses of shareholders. For example, there are considerable anxieties about organised corporate tax avoidance 
which increases corporate profits but simultaneously erodes the capacity of a society to invest in social infrastructure and redistribute wealth in pursuit of social stability and a fairer society. Accounting standards do not require companies to either disclose the corporate taxes they pay in each country ${ }^{17}$ of their operations, or the schemes used to avoid/evade taxes. Such information can also be obtained from corporate tax returns, but in pursuit of private competitive advantage, companies are also unwilling to publish them. The social perspective would require that tax information should be publicly available. The availability of tax information can empower stakeholders and enable to produce counter accounts and generate pressures for restraining anti-social practices (Sikka, 2011).

\subsection{Summary and Discussion}

This paper has sought to contribute to a body of literature that challenges the view that shareholders own large corporations or can invigilate their directors for the common good. It applied a number of tests of 'ownership' to show that the possession of shares is very distinct from the ownership of a large corporation. The ownership tests showed that shareholders have an entitlement to a future stream of economic surpluses, but that cannot be equated with ownership of companies. The paper made a distinction between investment in real capital and speculative investments and argued that shareholders are more likely to own fictitious rather than real capital. The imperatives of capitalism require holders of fictitious capital to pursue short-term gains and managers frequently respond by engaging in hostile takeovers, asset sales, leverage, share buybacks, financial engineering, wage reductions, tax avoidance, curtailment of research and development, environmental and other investments which can damage future shareholders and other stakeholders. In the contemporary environment, shareholders function as traders and speculators rather than as owners and have no intrinsic commitment to any community, nation state, or product as capital roams the world seeking higher

\footnotetext{
17 Following considerable civil society pressure, in May 2016, the European Union (http://eurlex.europa.eu/legal-content/EN/TXT/?uri=CELEX:52016PC0198) issued a directive under which companies with a total consolidated group revenue of at least $€ 750 \mathrm{~m}$ will be required to report information on revenues, profits, taxes paid, capital, earnings, tangible assets and the number of employees to the relevant tax authorities. This is popularly known as country-by-country reporting (CBCR), but will not form part of corporate financial reports.
} 
returns. Some support for such a contention was provided by changes in the UK shareholding patterns which showed that the duration of shareholding has considerably shrunk. Due to the global chase for higher returns, shareholders are more dispersed than ever before and cannot easily offer any collective invigilation of large companies.

The contemporary institutional attention is primarily focused on corporate governance and financial reporting for the benefit of fictitious capital (Financial Reporting Council, 2010, 2012; International Accounting Standards Board, 2011). It neglects the welfare of society and diverse stakeholders. This paper has argued for a stakeholder model of corporate governance so that corporations can be democratised and serve the needs of all stakeholders. It outlined contours of possible board structures, rights of stakeholders, and financial reporting practices though much more needs to be developed. The stakeholder approach essentially recognises that all wealth generation requires cooperation amongst various stakeholders: investors provide finance, employees provide brains, muscle and brawn and the state/society provides social infrastructure. However, the shareholder model and accompanying neoliberal theories (for example, agency theory) attach little weight to such cooperation and related risks. Instead, the corporation is treated as an asset and its ownership is reduced predominantly to a single constituency (shareholders) and a single objective of enriching shareholders. The shareholder model disenfranchises citizens who are assigned no responsibility and power for checking anti-social practices and management continue to escape obligations to other stakeholders. The emphasis on empowering shareholders necessitates greater appeasement of stock markets, speculation and short-termism, which adds to social instability, exploitation of stakeholders and excessive risk-taking. The shareholder primacy theories fail at the level of investors because, under pressure from some shareholders, management may pursue aggressive strategies to generate higher returns, but the same strategies may be harmful to other present and future investors (Stout, 2012). The aggressive pursuit of higher returns for shareholders is hollowing out companies and is shortening corporate life. Indeed, Denning (2011) notes that the average life expectancy of a Fortune 500 company has declined from around 75 years half a century ago to less than 15 years. 
Most of the current debates about corporate governance are rooted in property rights constructed around share ownership and financial returns. They were primarily crafted in the era before the emergence of civil society organisations and deeper concerns about the social and political power of large corporations. Increasingly, companies are being subjected to domestic and cross-border laws relating to human rights, bribery, corruption, money laundering and environmental damage (Sikka, 2008, 2011; Sikka and Lehman, 2015), and the tensions between private and public interests are likely to continue. There is some institutional recognition that the shareholder primacy model is dysfunctional, but governments seem to be unwilling or unable to implement major reforms as that would necessitate a bruising engagement with finance capital. For example, in its proposed revisions to the Shareholder Rights Directive, the European Parliament has stated that "Although they do not own corporations, which are separate legal entities beyond their full control, shareholders play a relevant role in the governance of those corporations" (European Parliament, 2015). A UK parliamentary investigation into the banking crisis recommended that "the Government consult on a proposal to amend Section 172 of the Companies Act $2006^{18}$ [which imposes some requirements to consider the interests of other stakeholders] to remove shareholder primacy in respect of banks, requiring directors of banks to ensure the financial safety and soundness of the company ahead of the interests of its members" (UK Parliamentary Commission on Banking Standards, 2013: 344). The UK government is sceptical of such recommendations and has not embarked on reforms (UK Department of Business Innovations and Skills and HM Treasury, 2013). In any case, the reforms need to go beyond the banking sector as the shareholder primacy model has been tainted in virtually every sector (Bratton, 2002; Bakan, 2004; Elliott and Atkinson, 2009; Davies, 2010; Friedman, 2010; Stiglitz, 2010; Hadden et al, 2014). Despite the contradictions, the shareholder model remains dominant in Anglo-Saxon countries and governments continue to postpone reforms (Walker, 2009; Financial Reporting

\footnotetext{
${ }^{18}$ For example, Section 172(1) of the UK's Companies Act 2006 states that "A director of a company must act in the way he considers, in good faith, would be most likely to promote the success of the company for the benefit of its members as a whole, and in doing so have regard (amongst other matters) to: (a) the likely consequences of any decision in the long term, (b) the interests of the company's employees, (c) the need to foster the company's business relationships with suppliers, customers and others, (d) the impact of the company's operations on the community and the environment, (e) the desirability of the company maintaining a reputation for high standards of business conduct, and (f) the need to act fairly as between members of the company.
} 
Council, 2010, 2012, 2013; UK Department of Business Innovation and Skills, 2011). Perhaps, the next economic crash or unexpected corporate collapse would create space for its displacement. In this context, research problematising the claims of shareholder primacy can be a valuable resource for transforming society. By disseminating research and analysis to wider audiences through popular media, critical scholars can help to reposition the common sense of the masses and create possibilities of structures that can enable the silenced voices of employees, local communities and other stakeholders to be heard. 
TABLE 1

Percentage of Total Market Value of UK Quoted Shares by Sector of Beneficial Owner

End year position for selected years 1963-2014

\begin{tabular}{|c|c|c|c|c|c|c|c|c|c|c|c|c|c|c|c|c|}
\hline & 1963 & 1969 & 1975 & 1981 & 1989 & 1990 & 1994 & 1997 & 2000 & 2002 & 2004 & 2006 & 2008 & 2010 & 2012 & 2014 \\
\hline Rest of the world & 7.0 & 6.6 & 5.6 & 3.6 & 12.8 & 11.8 & 16.3 & 28.0 & 35.7 & 35.9 & 36.3 & 40.0 & 41.5 & 43.4 & 53.6 & 53.8 \\
\hline Pension funds & 6.4 & 9.0 & 16.8 & 26.7 & 30.6 & 31.7 & 27.8 & 22.1 & 17.7 & 15.6 & 15.7 & 12.7 & 12.8 & 5.6 & 4.7 & 3.0 \\
\hline Unit trusts & 1.3 & 2.9 & 4.1 & 3.6 & 5.9 & 6.1 & 6.8 & 4.2 & 1.1 & 1.2 & 1.4 & 1.6 & 1.8 & 8.8 & 9.5 & 9.0 \\
\hline Investment trusts & ----- & ---- & ---- & ----- & 1.6 & 1.6 & 2.0 & 1.2 & 1.3 & 1.3 & 2.5 & 2.4 & 1.9 & 2.1 & 1.7 & 1.8 \\
\hline Other financial institutions & 11.3 & 10.1 & 10.5 & 6.8 & 1.1 & 0.7 & 1.3 & 1.3 & 2.8 & 7.7 & 8.2 & 9.6 & 10.0 & 12.3 & 6.6 & 7.1 \\
\hline Public sector & 1.5 & 2.6 & 3.6 & 3.0 & 2.0 & 2.0 & 0.8 & 0.1 & ---- & 0.1 & 0.1 & 0.1 & 1.1 & 3.1 & 2.7 & 2.9 \\
\hline Banks & 1.3 & 1.7 & 0.7 & $\underline{0.3}$ & 0.7 & $\underline{0.7}$ & 0.4 & 0.1 & 1.4 & 2.1 & $\underline{2.7}$ & 3.4 & 3.5 & 2.5 & 1.9 & 1.4 \\
\hline Total \% & $\underline{100}$ & 100 & $\underline{\underline{100}}$ & $\underline{\underline{100}}$ & $\underline{\underline{100}}$ & $\underline{\underline{100}}$ & 100 & 100 & 100 & $\underline{\underline{100}}$ & $\underline{\underline{100}}$ & 100 & $\underline{\underline{100}}$ & $\underline{\underline{100}}$ & $\underline{\underline{100}}$ & 100 \\
\hline
\end{tabular}

Source: Adapted from the UK Office for National Statistics (2015) and previous editions.

Due to rounding some columns may not add up to $100 \%$. 
TABLE 2

Shareholders' Equity and Total Capital in UK Listed Banks

\begin{tabular}{|l|c|c|c|c|}
\hline \multicolumn{1}{|c|}{ Company } & Year & $\begin{array}{c}\text { Gross assets (1) } \\
\text { Million }\end{array}$ & $\begin{array}{c}\text { Shareholder Funds (1) } \\
\text { Million }\end{array}$ & $\begin{array}{c}\text { Provided by } \\
\text { shareholders } \\
\text { (\%) }\end{array}$ \\
\hline Barclays Plc & 2015 & $£ 1,120,012$ & $£ 65,864$ & 5.88 \\
\hline HSBC Holdings plc & 2015 & $\$ 2,409,656$ & $\$ 197,518$ & 8.19 \\
\hline (2) Lloyds Banking Group plc & 2015 & $£ 806,688$ & $£ 46,980$ & 5.82 \\
\hline (3) Royal Bank of Scotland plc & 2015 & $£ 815,408$ & $£ 54,147$ & 6.64 \\
\hline (4) Banco Santander SA & 2015 & $€ 1,340,260$ & $€ 98,753$ & 7.36 \\
\hline Standard Chartered plc & 2015 & $\$ 640,483$ & $\$ 48,512$ & 7.57 \\
\hline
\end{tabular}

\section{Notes:}

(1) Information as per 2015 audited balance sheets published by companies.

(2) Lloyds Banking Group includes Lloyds Bank, Halifax, Bank of Scotland, TSB, Scottish Widows and Birmingham Midshires.

(3) Royal Bank of Scotland Group includes The Royal Bank of Scotland, National Westminster Bank, Ulster Bank, Citizens Financial Group, Charter One, Coutts Bank, RBS Securities, Isle of Man Bank, Dam and company, Churchill, Green Flag, Direct Line, Privilege and Lombard

(4) Santander is registered in Spain and has presence in the UK. It has also absorbed some well-known UK names, such as Abbey National, Alliance and Leicester and Bradford \& Bingley 


\section{References}

Accounting Standards Steering Committee, The Corporate Report, London: Accounting Standards Steering Committee, 1975.

American Institute of Certified Public Accountants, Study Group on the Objectives of Financial Statements: Objectives of Financial Statements. New York: AICPA, 1973 (The Trueblood Report).

Arnold, G. Corporate Financial Management (Fifth edition), London: Pearson, 2013.

Arnold, P. and Sikka, P. Globalization and the State-Profession Relationship: The case of the Bank of Credit and Commerce International, Accounting, Organizations and Society, 26(6): 475-499, 2001.

Asker, J., Collard-Wexler, A. and De Loecker, J. Dynamic Inputs and Resource (Mis)Allocation, Journal of Political Economy, 122(5): 1013-1063, 2014.

Bakan, J. The Corporation, New York: Free Press, 2004.

Bebbington, J., Gray, R. An account for sustainability: failure, success and a reconceptualization, Critical Perspectives on Accounting, 12(5): 557-588, 2001.

Berle, A.A. and Means, G.C. The Modern Corporation and Private Property, New Brunswick, N.J.: Transaction Publishers, 1991(originally published 1932)

Black, E., IBM and the Holocaust, London: Little Brown and Company, 2001.

Black, F. and Scholes, M. The Pricing of Options and Corporate Liabilities, Journal of Political Economy, 81(3): 637-654, 1973.

Bowman, A. Ismail Ertürk, I. Folkman, P. Froud, J. Haslam, C. Johal, S. Leaver, A. Moran, M. Tsitsianis, N. and Williams, K. What a Waste: Outsourcing and how it goes wrong, Manchester: Manchester University Press, 2015.

Bratton, W.W. Enron and the Dark Side of Shareholder Value, Tulane Law Review, 76(5/6): 1275-1305, 2002.

Bryer, R.A. The Mercantile Laws Commission of 1854 and the Political Economy of Limited Liability, Economic History Review, 50(1): 37-56, 1997.

Bullock, Lord, Report of the Committee of Inquiry on Industrial Democracy, Department of Trade, London: HMSO, 1977.

Ciepley, D. Beyond Public and Private: Toward a Political Theory of the Corporation, American Political Science Review, 107(1): 139-158, 2013.

Collison, D. Cross, S. Ferguson, J. Power, D. and Stevenson, L. Financialization and company law: A study of the UK Company Law Review, Critical Perspectives on Accounting, 25(4):5-16, 2014. 
Committee on the Financial aspects of Corporate Governance, The Financial Aspects of Corporate Governance, London: Gee, 1992 (Cadbury Report).

Committee on Corporate Governance, Committee on Corporate Governance: Final Report, London: Gee, 1998 (Hampel Report)

Connor, J.M. Global Price Fixing (2nd ed.), Springer, New York: Springer, 2007.

Cooper, C. Accounting for the fictitious: A Marxist contribution to understanding accounting's roles in the financial crisis, Critical Perspectives on Accounting, 30: 6382, 2015.

Davies, H. The Financial Crisis: who is to blame? Cambridge: Polity Press, 2010.

Davies, R., Haldane A., Nielsen, M. and Pezzini, S. Measuring the costs of shorttermism' Journal of Financial Stability, 12: 16-25. 2014

De Larosière, J. The High Level Group on Financial Supervision in the EU, Brussels: EU, 2009

(http://ec.europa.eu/internal_market/finances/docs/de_larosiere_report_en.pdf).

Demsetz, H. Information and Efficiency: Another Viewpoint, Journal of Law and Economics, 12(1): 1-22, 1969

Denning, S. Why Did IBM Survive? Forbes, 10 July 2011 (http://www.forbes.com/sites/stevedenning/2011/07/10/why-did-ibm-survive)/

Dodd, E. M. For Whom are Corporate Managers Trustees? Harvard Law Review, 45: 1145-1163, 1932.

Du Plessis, J.J. Großfeld, B. Luttermann, C. Saenger, S. Sandrock, O. and Casper. M. German Corporate Governance in International and European Context, New York: Springer, 2012.

Elliott, L. and Atkinson, D., The Gods That Failed: How the Financial Elite Have Gambled Away Our Futures London: Vintage, 2009.

Erkens, D.H., Hung, M. and Matos, P., Corporate governance in the 2007-2008 financial crisis: Evidence from financial institutions worldwide, Journal of Corporate Finance, 18(2): 389-411, 2012.

European Commission, Audit Policy: Lessons from the Crisis, Brussels, EU, 2010a (http://eurlex.europa.eu/LexUriServ/LexUriServ.do?uri=COM:2010:0561:FIN:EN:PDF ).

European Commission, Green Paper - Corporate governance in financial institutions and remuneration policies $\{\mathrm{COM}(2010) 285$ final $\}\{C O M(2010) 286$ final $\}\{S E C(2010)$ 669\}, Brussels: EU, 2010b (http://eur-lex.europa.eu/legalcontent/EN/ALL/?uri=CELEX:52010DC0284). 
European Commission, Green Paper - The EU corporate governance framework (COM(2011) 164 final), Brussels: EU, 2011

(http://ec.europa.eu/internal_market/company/docs/modern/com2011-164_en.pdf).

European Parliament, on the proposal for a directive of the European Parliament and of the Council amending Directive 2007/36/EC as regards the encouragement of long-term shareholder engagement and Directive 2013/34/EU as regards certain elements of the corporate governance statement (COM(2014)0213 - C7 0147/2014 - 2014/0121(COD)), 15 May 2015

(http://www.europarl.europa.eu/sides/getDoc.do?pubRef=-

//EP//TEXT+REPORT+A8-2015-0158+0+DOC+XML+V0//EN)

Financial Reporting Council, The UK Approach to Corporate Governance, London: FRC, $2010 \quad$ (http://www.frc.org.uk/getattachment/1db9539d-9176-4546-91ee828b7fd087a8/The-UK-Approach-to-Corporate-Governance.aspx)

Financial Reporting Council, The UK Corporate Governance Code, London: FRC, 2012a (http://www.frc.org.uk/Our-Work/Publications/Corporate-Governance/UKCorporate-Governance-Code-September-2012.aspx).

Financial Reporting Council, The UK Stewardship Code, London: FRC, 2012 (http://www.frc.org.uk/Our-Work/Publications/Corporate-Governance/UK-

Stewardship-Code-September-2012.pdf).

Financial Reporting Council, Directors' Remuneration: Consultation Document, London: FRC, 2013.

Friedman, J. What Caused the Financial Crisis, Philadelphia: University of Pennsylvania Press, 2010.

Friedman, M. The Social Responsibility of Business Is to Increase Its Profits, New York Times Magazine, 13 September 1970, pp. 32-33, 122-26.

Galbraith, J.K. The Great Crash 1929, Boston: Houghton Mifflin: 1961

Gong, B. Understanding Institutional Shareholder Activism: A Comparative Study of the UK and China, London: Routledge, 2014.

Greenfield, K. The Failure of Corporate Law: Fundamental Flaws and Progressive Possibilities, Chicago: University of Chicago Press, 2006.

Hadden, T. Ireland, P. Morgan, G. Parker, M. Pearson, G. Picciotto, S. Sikka, P, and Willmott, H. Fighting Corporate Abuse Beyond Predatory Capitalism, London: Pluto, 2014.

Haldane, A.G. Patience and Finance, Speech at Oxford China Business Forum, Beijing, 2 September 2010

(http://www.bankofengland.co.uk/archive/Documents/historicpubs/speeches/2010/sp eech445.pdf). 
Haldane, A.G., Control rights (and wrongs), Wincott Annual Memorial Lecture, London, 24 October 2011a

(http://www.bankofengland.co.uk/publications/Documents/speeches/2011/speech52 5.pdf).

Haldane, A.G. Accounting for bank uncertainty, 19 December 2011b (http://www.bankofengland.co.uk/publications/Documents/speeches/2012/speech54 0.pdf).

Haldane, A.G., Who Owns a Company? Speech given at the University of Edinburgh Corporate Finance Conference, 22 May 2015 (http://www.bankofengland.co.uk/publications/Documents/speeches/2015/speech83 3.pdf)

Handy, C. Beyond Certainty: The Changing Worlds of Organizations. London: Hutchinson, 1995.

Hansmann, H. and R. Kraakman, The End of History for Corporate Law, Georgetown Law Journal, 89(1): 439-468, 2001.

Harvey, D. The Enigma of Capital and the Crises of Capitalism, Oxford: Oxford University Press, 2010.

Haslam, C. Tsitsianis, N. Hoinaru, R. Andersson, T and Katechos, G. Stress Testing International Financial Reporting Standards (IFRS): Accounting for Stability and the Public Good in a Financialized World, Accounting, Economics and Law - A Convivium, ISSN (Online) 2152-2820, ISSN (Print) 2194-6051, DOI: 10.1515/ael2015-0006, November 2015

Hawley, S. Exporting Corruption Privatisation, Multinationals and Bribery, Sturminster Newton: The Corner House, 2000.

Hicks, A. and Goo, S.H. Cases and Materials on Company Law (6th edition), Oxford: Oxford University Press, 2008.

Hilt, E. and O'Banion. K. The Limited Partnership in New York 1822-1858: Partnerships Without Kinship, Journal of Economic History, 69(3): 615-645, 2009.

Honore, A.M. 'Ownership' in A.G.Guest (ed), Oxford Essays in Jurisprudence, Oxford: Clarendon Press, 1961.

Hunt, B.C. The Development of the Business Corporation in England, 1800-1867, Cambridge, MA: Harvard University Press, 1936

International Accounting Standards Board, Agenda Paper 7A - Conceptual Framework for Financial Reporting Chapter 1: The Objective of Financial Reporting, September 2007

(http://www.ifrs.org/Meetings/MeetingDocs/IASB/Archive/ConceptualFramework/Previous\%20Work/CF-0709b07a-attA.pdf). 
International Accounting Standards Board, Conceptual Framework: International Financial Reporting Standards 2011, London: IASB, 2011.

Ireland, P. Company Law and the Myth of Shareholder Ownership, Modern Law Review, 62(1): 32-57, 1999.

Ireland, P. Shareholder Primacy and the Distribution of Wealth. The Modern Law Review, 68(1): 49-81, 2005.

Ireland, P. Limited liability, shareholder rights and the problem of corporate irresponsibility, Cambridge Journal of Economics, 34(5), 837-856, 2010.

Jackson, J.K. Foreign Ownership of U.S. Financial Assets: Implications of a Withdrawal, Washington DC: Congressional Research Service, 2008 (http://www.fas.org/sgp/crs/natsec/RL34319.pdf).

Jensen, M. and Meckling, W., Theory of the firm: managerial behavior, agency costs and ownership structure", Journal of Financial Economics, 3(4): 305-360, 1976.

Kay, J. The Kay Review of UK Equity Markets and Long-Term Decision Making, London: UK Department of Business, Innovation and Skills, 2012.

Kempin Jr., F.G. Limited Liability in Historical Perspective, in C.W. Gillam and W. Zelermyer (eds.), American Business Law Association Bulletin, Vol. 4 No.1, Bowling Green, Ohio: 1960, pp. 11-34.

Lazonick, W. Profits Without Prosperity, Harvard Business Review, 92(9): 46-55, September 2014.

Lewis, R. and Pendrill, D. Advanced Financial Accounting (sixth edition), Harlow: Pearson Education, 2000.

London Stock Exchange, Introduction to London Stock Exchange: Capital Markets. London. LSE, 2015 (http://www.Iseg.com/sites/default/files/content/documents/LSE\%20Capital\%20Mark ets\%20brochure\%202015.pdf).

Manne, $\mathrm{H}$. Mergers and the market for corporate control, Journal of Political Economy, 73(2): 110-120, 1965.

Marx, K. Capital: Volume 2, London: Penguin, 1978 (Introduced by Ernest Mandel).

Marx, K. Capital: Volume 3, London: Penguin, 1981 (Introduced by Ernest Mandel).

Meyer, C. Firm Commitment: Why the corporation is failing us and how to restore trust in it, Oxford: Oxford University Press, 2013.

Micklethwait, J. and Wooldridge, A. The Company: A Short History of a Revolutionary Idea, London: Phoenix, 2005. 
Mitchell, A. and Sikka, P. Taming the Corporations, Basildon: Association for Accountancy \& Business Affairs, 2005.

Mitchell, A. and Sikka, P. The Pin-Stripe Mafia: How Accountancy Firms Destroy Societies, Basildon: Association for Accountancy \& Business Affairs, 2011

Modigliani, F. and Miller, M. H. The Cost of Capital, Corporate Finance and the Theory of Investment. American Economic Review, 48(3): 261-97, 1958.

Modigliani, F. and Miller, M. H. Corporate Income Taxes and the Cost of Capital: A Correction. American Economic Review, 53(3): 433-43, 1963.

Morck, R.A. A History of Corporate Governance around the World: Family Business Groups to Professional Managers, Chicago: University of Chicago Press, 2007.

Munzer, S.R. A Theory of Property, Cambridge: Cambridge University Press, 1990.

Myners, P. Institutional Investment in the United Kingdom: A Review, London: HM Treasury, 2001.

O'Connor, J. The Meaning of Crisis: A Theoretical Introduction, Oxford: Basil Blackwell, 1987.

O'Sullivan, M. Contests for Corporate Control: Corporate Governance and Economic Performance in the United States and Germany, Oxford: Oxford University Press, 2000.

Organisations for Economic Cooperation and Development, OECD Principles of Corporate Governance, Paris: OECD, 2004

Plantin, G., Sapra, H. and Shin, H.S. Marking-to-Market: Panacea or Pandora's Box? Journal of Accounting Research, 46(2): pp. 435-460, 2008.

Pope, P.F. and Puxty, A.G. What is Equity? New Financial Instruments in the Interstices between the Law, Accounting and Economics, Modern Law Review, 54(6): 889-911, 1991.

Riahi-Belkaoui, A. Value Added Reporting and Research: State of the Art, Westport, CT: Quorum, 1999.

Roland, G. Privatization: Successes and Failures: New York: Columbia University Press, 2008.

Saville, J. Sleeping Partnership and Limited Liability, 1850-1856, Economic History Review, 8(3): 418-33, 1956.

Sharman, A. Foreign takeovers revive talk of UK decline, Financial Times, 8 September $2013 \quad$ (http://www.ft.com/cms/s/0/a0ea0bb8-08d7-11e3-8b3200144feabdc0.html\#axzz2mc6XRWxB). 
Sikka, P. Enterprise Culture and Accountancy Firms: New Masters of the Universe", Accounting, Auditing and Accountability Journal, 21(2): 268-295, 2008.

Sikka, P. Accounting for human rights: The challenge of globalization and foreign investment agreements", Critical Perspectives on Accounting, 22(8): 811-827, 2011

Sikka, P. Banking in the public interest: Progressive reform of the financial sector, London: CLASS, 2014

(http://classonline.org.uk/docs/2014_Banking_in_the_public_interest__Prem_Sikka.pdf)

Sikka, P. The hand of accounting and accountancy firms in deepening income and wealth inequalities and the economic crisis: Some evidence, Critical Perspectives on Accounting, 30: 46-63, 2015.

Sikka, P., and Lehman, G. Supply-side corruption and Limits to Preventing Corruption within Government Procurement and Constructing Ethical Subjects, Critical Perspectives on Accounting, 28: 62-70, 2015.

Sikka, P and Willmott, H. Illuminating the State-Profession Relationship: Accountants Acting as Department of Trade and Industry Investigators, Critical Perspectives on Accounting, 6)4): 341-369, 1995.

Smith, A. An Inquiry into the Nature and Causes of the Wealth of Nations, London: W. Strahan and T. Cadell, 1776 (download available at http://www2.hn.psu.edu/faculty/jmanis/adam-smith/wealth-nations.pdf).

Soederburg, S. Corporate Power and Ownership in Contemporary Capitalism, New York: Routledge, 2010.

Somerset-Webb, M. Slow death of equity markets is bad news, Financial Times, 27 March $2015 \quad$ (http://www.ft.com/cms/s/0/fd1fc2e2-d46e-11e4-8be800144feab7de.html\#axzz3rUccwf75)

Staubus, G.J. The decision-usefulness theory of accounting: a limited history. New York: Garland, 2000.

Staubus, G.J. Response to Preliminary Views: The Conceptual Framework, London: IASB, July 2006 (http://www.ifrs.org/Current-Projects/IASB-Projects/ConceptualFramework/DPJul06/Comment-Letters/Documents/CL23.pdf).

Sternberg, E. Corporate Governance: Accountability in the Marketplace. London: The Institute of Economic Affairs, 2004.

Stiglitz, J.E., Freefall: America, Free Markets, and the Sinking of the World Economy, New York: W.W. Norton, 2010.

Stout, L. The Shareholder Value Myth: How Putting Shareholders First Harms Investors, Corporations, and the Public, San Francisco: Berrett Keohler, 2012. 
Sun, W. Stewart, J. and Pollard, D. Corporate Governance and the Global Financial Crisis: International Perspectives, Cambridge: Cambridge University Press, 2011.

Sunder, S. Extensive Income and Value of the Firm: Who Gets What? October 2008 (available at http://faculty.som.yale.edu/shyamsunder/Value-Oct3008.pdf).

Talbot, L. Progressive Corporate Governance for the 21st Century, London: Routledge, 2013.

UK Department of Business Innovations and Skills, UK Government Response to the Green Paper: The EU corporate governance framework, London: DBIS, 2011 (http://ec.europa.eu/internal_market/consultations/2011/corporate-governanceframework/public-authorities/uk-government_en.pdf).

UK Department of Business Innovations and Skills, and HM Treasury, Cm 8661: The Government's response to the Parliamentary Commission on Banking Standards, London: TSO, July 2013.

UK Financial Services Authority, The Turner Review: A regulatory response to the global banking crisis, London: FSA, March 2009 (The Turner Review) (http://www.fsa.gov.uk/pubs/other/turner_review.pdf).

UK House of Commons Treasury Committee, Banking Crisis: reforming corporate governance and pay in the City. London: The Stationery Office, 2009.

UK Office for National Statistics, Ownership of quoted shares for UK domiciled companies 2014, London: ONS, September 2015

(http://www.ons.gov.uk/ons/dcp171778_415334.pdf).

UK Parliamentary Commission on Banking Standards, Changing banking for good (Vols. I - VIII), London: the Stationery Office, 2013.

Walker, D. A review of corporate governance in UK banks and other financial industry entities: Final recommendations, London: HM Treasury, 2009 (http://webarchive.nationalarchives.gov.uk/20130129110402/http://www.hmtreasury.gov.uk/d/walker_review_261109.pdf).

Willmott, $\mathrm{H}$. and Veldman, J. 'Reimagining the Corporation: The Relevance of Legal, Economic and Political Imaginaries' in J. Haslam and P. Sikka (eds.), Pioneers of Critical Accounting: A Celebration of the Life of Tony Lowe, London: Palgrave Macmillan, 2016. 